\title{
Challenges in utilization and management of water resources of the Camenca river basin in the context of intensified human impact
}

\author{
Petru Bacal ${ }^{1 凶}$, Ana Jeleapov ${ }^{1}$ \\ ${ }^{1}$ Institute of Ecology and Geography, Chisinau, Republic of Moldova.
}

\begin{abstract}
This article is dedicated to the evaluation of water use and management of 12 river water bodies delineated in the Camenca river basin - the biggest tributary of the Prut River in the limits of the Republic of Moldova. The study is based on the approaches and methodology proposed by the EU Water Framework Directive and its methodological guidelines as well as on the national normative documents. The present research was conducted as part of the Camenca river basin management plan and constitutes the basis for the development of the Programme of Measures meant to accomplish the environmental objectives established for water bodies. Considering water use problems in the limits of the pilot basin, in the present research several challenges were identified: intensification of climate change and reduction of water supply; reduced accessibility of the population to aqueducts and the lack of public sewerage systems; significant impact of diffuse pollution on agriculture; a large number of reservoirs in improper conditions. With regards to water resources management, the following issues were revealed: incomplete inventory of water resources and frequent cases of unauthorised water use; low prices for water supply and sewerage services as well as for water use and water pollution, which do not cover water use costs and investments in water resources and aquatic ecosystems protection; insufficient and fragmented subventions in water sector; issues regarding legal framework and adequate exploitation regime of reservoirs, etc.
\end{abstract}

Keywords: the Camenca river basin, water use, water management.

\begin{abstract}
Résumé. Cet article est consacré à l'évaluation de l'utilisation et de la gestion des ressources en eau de 12 plans d'eau délimitées dans le bassin de la rivière Camenca - le plus grand affluent de la rivière Prut sur le territoire de la République de Moldova. L'étude est basée sur les approches et la méthodologie proposées dans la Directive-Cadre sur l'Eau de l'UE et ses guides méthodologiques, ainsi que sur les documents normatifs nationales. Ce travail a été réalisé pour l'élaboration du Plan de Gestion du bassin de la rivière Camenca et constitue la base de l'élaboration du Programme de Mesures visant à atteindre les objectifs environnementaux des plans d'eau. Du côté de l'utilisation des ressources en eau dans la zone d'étude, la présente
\end{abstract}

\section{CORRESPONDENCE:}

Institute of Ecology and Geography, Academiei str., 1, MD-

2028, Chisinau, the Republic of Moldova.
ARTICLE HISTORY :

Received : 30 June 2019

Received in final form : 22 October 2019

Accepted : 26 October 2019 


\begin{abstract}
étude identifie quelques problèmes principaux: l'intensification du changement climatique et la réduction de l'approvisionnement en eau; accès réduit de la population aux aqueducs et manque massif de systèmes publics d'assainissement; l'impact significatif de la pollution diffuse dans l'agriculture ; le grand nombre de lacs d'accumulation et leur état inapproprié. En ce qui concerne la gestion des ressources notre analyse a conduit à l'identification d'autres difficultés: l'enregistrement incomplet des ressources en eau et cas fréquents d'utilisation non autorisée de l'eau; le faible niveau des tarifs pour l'approvisionnement en eau et l'assainissement et des taxes pour l'utilisation et la pollution de l'eau, qui n'assurent pas la récupération des coûts d'utilisation de l'eau et le financement des investissements pour la protection des sources d'eau et des écosystèmes aquatiques; le subventionnement insuffisant et fragmenté du secteur; les litiges concernant le droit et le régime d'exploitation des lacs d'accumulation, etc.
\end{abstract}

Mots-clés: le bassin de la rivière Camenca, utilisation de l'eau, gestion de l'eau

\title{
1. Introduction
}

Main purpose of EU Water Framework Directive (WFD) is to establish a framework for the protection of surface waters (inland, transitional, coastal) and groundwater (Directive 2000/60/EC). The main way to perform this task is to develop and implement the river basin management plans prepared for a 6 years period, for 3 cycles (2009-2015, 2015-2021, 2021-2027). The Danube River Basin Management Plan (the II ${ }^{\text {nd }}$ cycle) can serve as an example of such a plan (the Danube River Basin Management Plan 2015-2021). In the Republic of Moldova, WFD was partially adapted by national legislation (RMGD, 2013a, 2013b; RM Law, 2011, 2013) and constitutes the base for development of management plans of 2 main districts: the Dniester and the Danube-Prut and Black Sea. The management plans of these districts were approved in 2017 and 2018 by Government Decisions, both being of Ist cycle (RMGD, 2018, 2017). As subsequent activities, the development of management plans of tributaries of the Prut and Dniester has begun. One of these tributaries is the Camenca river - the tributary of the Prut river, to which this study is dedicated.

The water resources of the Camenca river are used for different purposes but due to limited river flow, human impact and climate change, the river status degrades from one year to another. In order to improve water resources quality and quantity the Camenca River Basin Management Plan was developed. In this regard, the present study was performed as a part of the Plan and was dedicated to evaluation of utilization and management of water resources of the Camenca River Basin. The main objectives of the research are: a) estimation of water bodies water resources; b) diagnosis of water use status and elaboration of recommendations to prevent problematic situations in this regard; c) analysis of prices and costs for water supply and centralized sewerage system status, d) definition of priority directions for optimization of water resources management. 
The research was performed within the project "Development of Integrated Management Plan of Camenca River Basin" implemented by AO "Women's Association for Environmental Protection and Sustainable Development", based on the grant from SDC/ADA Project "Strengthening the institutional framework in the water and sanitation in the Republic of Moldova (Phase 01)", managed by the "Apele Moldovei" Agency.

\section{Study area}

The Camenca river is one of the biggest tributaries of the Prut river in the limits of the Republic of Moldova territory. Its basin is located in the middle course of the Prut River, comprising practically the natural unit Middle Prut Plain, situated in the northwest part of the country (Figure 1). The total area of the basin is $1237 \mathrm{~km}^{2}$. The total length of the Camenca river is $108.5 \mathrm{~km}$. The Camenca river springs $3 \mathrm{~km}$ north of Borosenii Noi village and flows into the Prut river, on the left bank, at $466 \mathrm{~km}$ from its mouth, $1.5 \mathrm{~km}$ south to the village of Pruteni. The total fall is $136 \mathrm{~m}$ (Bejan et al., 2019; Cazac et al., 2010). The most important tributaries from Camenca river are Caldarusa (41 km), Glodeanca (31 km), Sovatul Mic (44 km), Sovatul Mare (26,5 km), Camencuta $(20,6 \mathrm{~km})$.

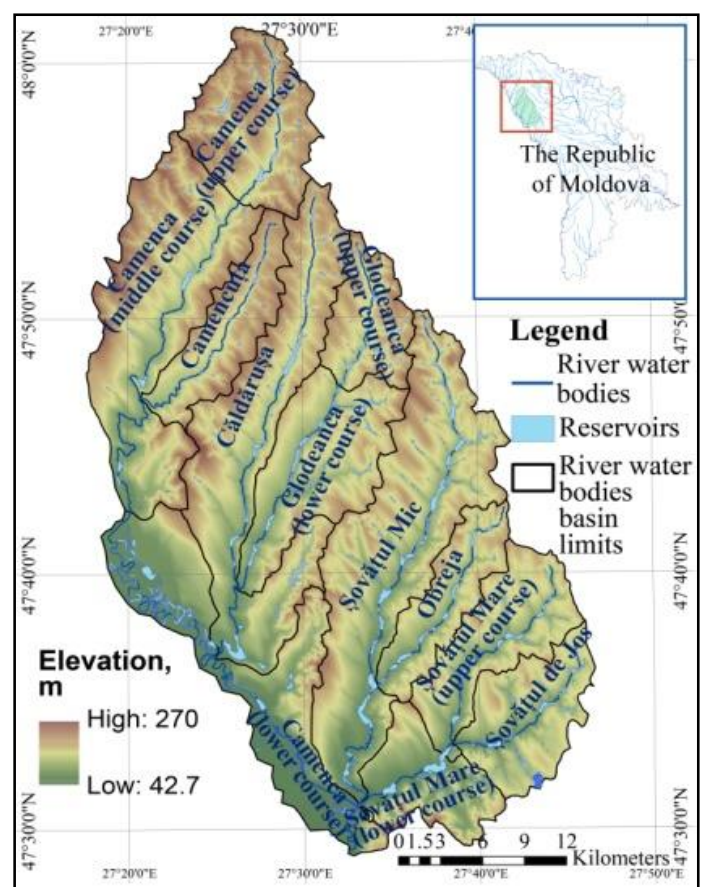

Figure 1. Elevation and surface water bodies of the Camenca river basin

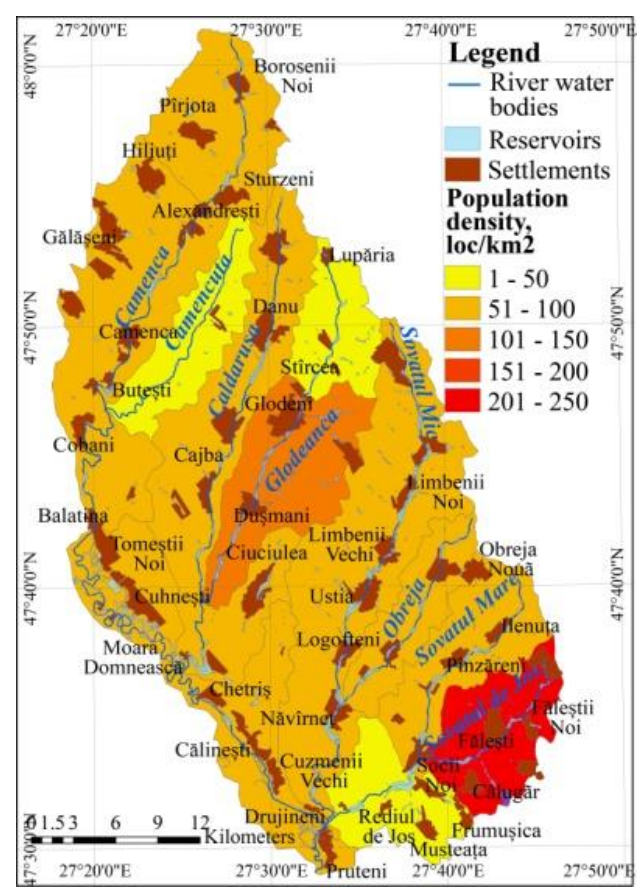

Figure 2. Population density in the Camenca river basin

According to the management plan of the Danube-Prut and Black Sea basin 
district (RMGD, 2018), the total number of river water bodies delineated in the Camenca river basin (RB) is 12 (Figure 1). The Camenca river was segmented in 3 water bodies that approximately represent upper, middle and lower course of the river.

In the perimeter of the Camenca river basin, there are located 75 settlements from 3 administrative districts (Rascani, Glodeni and Falesti), including 2 cities (Glodeni and Falesti) and 41 commune centers (Figure 2). The average population density is 72 inhabitants $/ \mathrm{km}^{2}$. The maximum density is specific for water bodies (WB) in whose basins urban areas are located. For example, the density of 233 inhabitants $/ \mathrm{km}^{2}$ is was estimated for the Sovatul de Jos WB basin (where Falesti town is located) and of 126 inhabitants $/ \mathrm{km}^{2}$ - for the Glodeanca WB basin (where Glodeni town is located). The minimum density is characteristic for the Camencuta WB basin - 0.7 inhabitants $/ \mathrm{km}^{2}$ and the Glodeanca WB basin (upper part) - 10 inhabitants $/ \mathrm{km}^{2}$ (density was calculated based on data from NBS 2005, 2015).

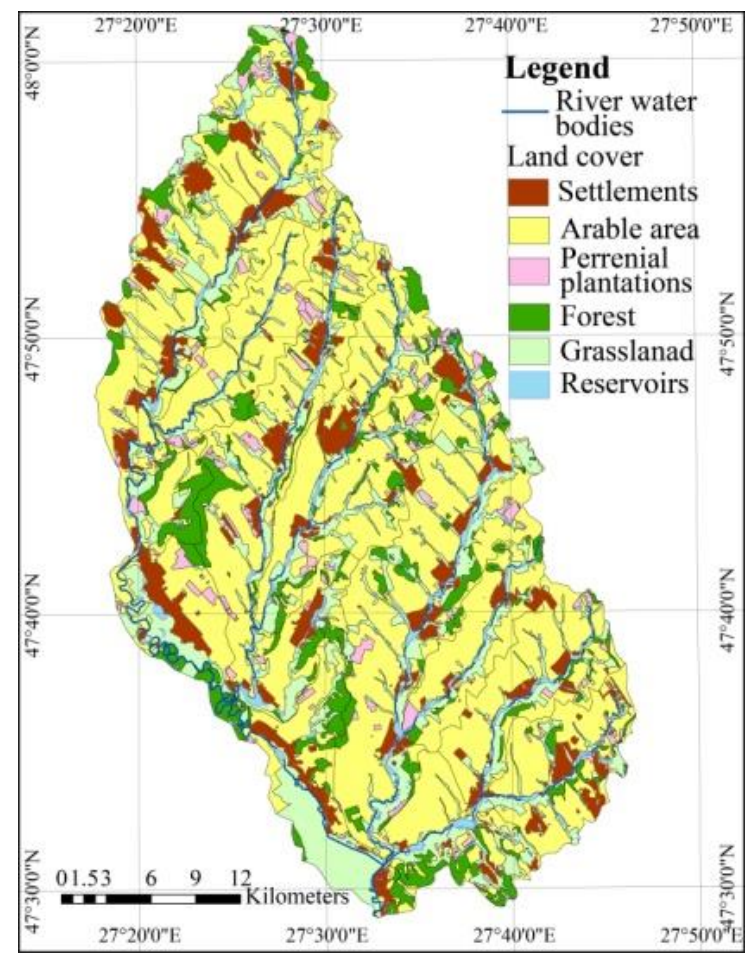

Figure 3. Land cover in the Camenca river basin

According to land use type, the Camenca river basin is a typical agrarian region. Agricultural lands occupy approximately 77\% (Figure 3). More than half of the basin area is occupied by arable area (55\%). Pastures cover $19 \%$ of the total area of 
the basin, and are mainly represented as riparian buffer in rivers floodplains (Bejan et al., 2019).

\section{Material and methods}

The realization of present research was based on recent analytical studies and methods used for the river basins management plan recommended by EU WFD (Directive 2000/60/EC) as well as the Danube River Basin Management Plan (the Danube River Basin Management Plan 2015-2021), River Basin Management Plan of Prut-Barlad (ANAR, 2016) and Management Plan of Prut river basin (RMGD, 2018).

The main informational and statistical support of this study included: 1) Generalized Annual Reports on Water Management Indicators elaborated by the Basins Department of "Apele Moldovei" Agency (AAM, 2007-2017); 2) Annual Reports of Ecological Agencies and Inspection (IPM, 2018); 3) analytical studies in this field, including some papers published by the authors of this article (Bejan et al., 2016; Bejan et al., 2019; Jeleapov and Jeleapov, 2018). The study comprised the information for the period 2007-2017.

Spatial information was partly extracted from National Geodata Fund (NGF, 2018) and processed by using QGIS.

The main methods used are the following: statistical, analytical, comparative methods, as well as consultations with competent authorities and experts in the field of assessing and managing of water resources. Statistical method was widely used for processing the statistical information on water use in the river basins of Republic of Moldova. The analytical method was used for: a) identification of quantitative and qualitative aspects of water use; b) diagnosis of situation of water use and elaboration of recommendations to prevent problematic situations in this field; d) definition of priority directions of activity optimization of water resources management in the river basins. The comparative method was applied for establishing the trends in the water use types and spatial aspects. The methodology stipulated in the WATECO Guidance on the Economic Assessment of Water Uses (Guidance document no. 1., 2003) was also applied, especially for assessment of volume and tendencies of water use and for identification of main problems in water supply sector.

Assessment of hydrological characteristics of rivers and water bodies was performed using direct and indirect methods from a national normative document (CP D.01.05-2012, 2013). Application of direct methods was performed by analysis of time series from gauging stations of the hydrologic monitoring network managed by State Hydrometeorologic Service (Cadastru de Stat al Apelor, 2006; Cazac et al., 2010; SHS 2011-2017). In the limits of the Camenca river basin hydrologic information is present for the Caldarusa river - station Cajba for the period 1951-2014 and for the 
Camenca river - station Cobani for 1947-1986. As it can be observed, at present, hydrologic monitoring is absent in the basin. Also, information from State Hydrometeorologic Service was used for estimation of water quality status (SHS 2011-2017).

Human impact assessment was performed using the approach Driver-PressureState-Impact-Response which consists in the identification of the cause-effect link that determines the water body degradation, but also the measures to be taken to rehabilitate it (Bejan et al., 2019; Vogel, 2014). In this study the focus was on estimation of:

1. point pollution sources impact due to: total amount of wastewater discharge.

2. diffuse pollution sources impact due to: (1) agricultural activities and (2) animal livestock.

3. hydro-morphological changes due to: (1) reservoirs, (2) protection embankments and (3) irrigation channels.

4. hydrological changes induced by: (1) agricultural activities, (2) urbanization process and (3) reservoirs.

Detailed methodology is described in the normative documents (CP D.01.052012, 2013, Directive 2000/60/EC; Directive 2006/118/EC, Directive 91/676/EC), annual reports of Hydro-Meteorological Service (Cadastru de Stat al Apelor, 2006; SHS 20112017) and analytical studies of authors of this paper (Bejan et al., 2019; Jeleapov and Jeleapov, 2018).

\section{Result and discussions}

\subsection{The problems of water use and protection in the Camenca river basin}

\subsubsection{Limited water resources and increased vulnerability to climate change}

The Camenca river basin is poorly assured with surface water resources. Based on existing monitoring information it was estimated that average annual discharges of the Camenca and Caldarusa rivers are $0.46 \mathrm{~m}^{3} / \mathrm{s}$ and $0.15 \mathrm{~m}^{3} / \mathrm{s}$. The average annual runoff is $54 \mathrm{~mm}$ for Camenca and $58 \mathrm{~mm}$ for Caldarusa. The average annual water volume is $15.3 \mathrm{mil} . \mathrm{m}^{3}$ and $4.6 \mathrm{mil} . \mathrm{m}^{3}$ for the two rivers.

The calculated average discharge of water bodies is in the range of 0.11 (the Obreja WB) - $1.29 \mathrm{~m}^{3} / \mathrm{s}$ (the Camenca WB (lower course)). The runoff represents minimal values for the Sovatul Mare WB (lower course) - $31.7 \mathrm{~mm}$, and maximal for the Camenca WB (upper course) - $43.8 \mathrm{~mm}$. Due to limited water resources, these rivers present only local economic importance. In addition, a big number of ponds and reservoirs is constructed on WBs streams, fact that significantly affects the 
hydrological and hydro-morphological status, as well as floodplain ecosystems of the study area. In the process of planning water resources use and construction of new hydro-technical structures (reservoirs), it is compulsory to take into account the degree of assurance with water resources.

Assessing the groundwater bodies' quality, it can be concluded that waters are not favorable for drinking water supply due to the amount of dry residual value, sodium and fluoride content. They can only be used for water supply after a pretreatment. Water bodies ",at risk" are mainly found in alluvial-delluvial, Holocene aquifer (Bejan et. al., 2019).

The current climatic conditions in the basin are characterized by a stable trend of warming, fact confirmed by seasonal and annual air temperature evolution. In the last decades, both in the transitional seasons (spring - autumn) and of the antipodes (winter-summer) a substantial increase of the temperature values is detected (Bejan et al., 2019).

Thus, in several rural settlements an acute water deficit is observed, caused by the limited available water resources, the intensification of climate change and the significant reduction of the surface runoff determined by the excessive number of reservoirs and by their mismanagement.

\subsubsection{The peculiarities of water use for main water-use categories}

The total volume of water used in the Camenca river basin was, on average, 2.7 mil. $\mathrm{m}^{3}$ (Table 1) or $15 \%$ of the water used in the Prut river basin. In Falesti district there were used, on average, $1.2 \mathrm{mil} . \mathrm{m}^{3}$, in Glodeni district $-1.1 \mathrm{mil} . \mathrm{m}^{3}$, and in Rascani district - only $\approx 300$ ths. $\mathrm{m}^{3}$ of water. The maximum volume of water was used by the municipal enterprises from Falesti $\left(452\right.$ ths. $\left.\mathrm{m}^{3}\right)$ and Glodeni $\left(165\right.$ ths. $\left.\mathrm{m}^{3}\right)$ towns and from rural settlements with larger aqueducts, by the sugar factories from Glodeni (303 ths. $\mathrm{m}^{3}$ ) and Falesti (234 ths. $\left.\mathrm{m}^{3}\right)$, as well as by the large agricultural enterprises from Rascani district.

The total volume of water used in the Camenca river basin shows an oscillating evolution (Table 1, Figure 4) against the background of a generally negative tendency. Also, the negative dynamics can be observed only in Glodeni district, where the volume of water used decreased by $\approx 1 / 4$. This fact was is caused by, almost exclusively, reduction by 6 times of volume of water used by sugar factory from Glodeni town, which now is closed. The maximum volume of water use is recorded in dry 2012, fact caused by waters abstracted to satisfy, especially, the agricultural needs in Falesti district. Subsequently, a tendency of slow reduction in water use is attested, which was interrupted in 2017, especially due to the extension of aqueducts in rural areas, as well as to the maximum volumes of water used by agricultural companies from Rascani district.

L.S.G.D.C. 47 (1): $75-97$ 
Table 1. Dynamics of the total volume of water used in Camenca river basin, in ths. $\mathrm{m}^{3}$

\begin{tabular}{lccccccccccccc}
\hline Districts & \multicolumn{10}{c}{ Years } & average \\
& \cline { 2 - 7 } & $\mathbf{2 0 0 7}$ & $\mathbf{2 0 0 9}$ & $\mathbf{2 0 1 0}$ & $\mathbf{2 0 1 1}$ & $\mathbf{2 0 1 2}$ & $\mathbf{2 0 1 3}$ & $\mathbf{2 0 1 4}$ & $\mathbf{2 0 1 5}$ & $\mathbf{2 0 1 6}$ & $\mathbf{2 0 1 7}$ & \\
\hline Rascani & 390 & 300 & 321 & 302 & 284 & 275 & 264 & 225 & 253 & 241 & 416 & 297 \\
Glodeni & 1280 & 1370 & 1180 & 1190 & 1220 & 1250 & 1550 & 1220 & 1060 & 1000 & 991 & 1210 \\
Falesti & 938 & 1005 & 965 & 1052 & 925 & 1896 & 1286 & 1206 & 1089 & 1056 & 1170 & 1144 \\
Camenca RB & $\mathbf{2 6 0 8}$ & $\mathbf{2 6 7 5}$ & $\mathbf{2 4 6 6}$ & $\mathbf{2 5 4 3}$ & $\mathbf{2 4 2 8}$ & $\mathbf{3 4 2 1}$ & $\mathbf{3 1 0 0}$ & $\mathbf{2 6 5 1}$ & $\mathbf{2 4 0 2}$ & $\mathbf{2 2 9 7}$ & $\mathbf{2 5 7 7}$ & $\mathbf{2 6 5 2}$ \\
\hline
\end{tabular}

Data sources: (AAM 2007-2017; NBS 2007-2017; IPM 2018).

The volume of water used from surface sources has registered a pronounced decrease ($20 \%$ ), however this fact is observed only in Glodeni district. Here, the volume of water abstracted from surface sources has decreased by $\approx 3$ times, which is due, almost exclusively, to the sugar factory. At the same time, the increase by more than $60 \%$ of water abstracted from surface sources in Rascani district is caused by large agricultural companies. The volume of water used from groundwater sources, overall, is positive (+14\%), which is conditioned by extension of aqueducts, especially in rural settlements.

If we take into account the average values for the entire analyzed period, then the volume of water used for domestic and agricultural purposes is almost identical, about 1.1 mil. $\mathrm{m}^{3}$ or $42 \%$ of the total water used in the Camenca river basin (Table 2). For technological needs there were used, on average, $16 \%$ (453 ths. $\mathrm{m}^{3}$ ) of the total, from this over $90 \%$ - at sugar factories.

Table 2. Volume and share of water used on the main water-use categories

\begin{tabular}{|c|c|c|c|c|c|c|c|c|c|c|c|c|c|c|c|c|}
\hline \multirow{4}{*}{ Districts } & \multicolumn{8}{|c|}{ Average } & \multicolumn{8}{|c|}{2017} \\
\hline & \multicolumn{2}{|c|}{ household } & \multicolumn{2}{|c|}{ industry } & \multicolumn{4}{|c|}{$\begin{array}{l}\text { agriculture, incl. } \\
\text { irrigation }\end{array}$} & \multicolumn{2}{|c|}{ household } & \multicolumn{2}{|c|}{ industry } & \multicolumn{4}{|c|}{$\begin{array}{l}\text { agriculture, incl. } \\
\text { irrigation }\end{array}$} \\
\hline & ths & $\%$ & ths & $\%$ & ths & $\%$ & ths & $\%$ & ths & $\%$ & ths & $\%$ & ths & $\%$ & ths & $\%$ \\
\hline & $\mathrm{m} 3$ & & $\mathrm{~m} 3$ & & $\mathrm{~m} 3$ & & $\mathrm{~m} 3$ & & $\mathrm{~m} 3$ & & $\mathrm{~m} 3$ & & $\mathrm{~m} 3$ & & $\mathrm{~m} 3$ & \\
\hline Rascani & 60,8 & 20 & 10 & 3,4 & 226 & 76 & 120 & 40 & 126 & 30 & 3,8 & 0,9 & 286 & 69 & 209 & 50 \\
\hline Glodeni & 490 & 41 & 226 & 17 & 512 & 42 & 67 & 5,6 & 703 & 71 & 47 & 4,8 & 242 & 25 & 40 & 4,1 \\
\hline Falesti & 551 & 48 & 225 & 20 & 368 & 32 & 182 & 16 & 848 & 72 & 173 & 15 & 149 & 13 & 70 & 6,0 \\
\hline Camenca RB & 1100 & 42 & 453 & 17 & 1117 & 42 & 249 & 9,4 & 1677 & 65 & 224 & 8,8 & 677 & 26 & 319 & 12 \\
\hline
\end{tabular}

The volume of water used in agriculture, especially for irrigation, depends on the availability of water sources such as rivers and reservoirs with sufficient volumes, as well as on the presence of large agricultural companies. On average, around 250 ths. $\mathrm{m}^{3}$ of water (9.4\% of the total volume) is being used for irrigation.

The volume of water used for agricultural purposes decreased by about 2.5 times (from 1.7 mil. $\mathrm{m}^{3}$ to 677 ths. $\mathrm{m}^{3}$ ), it has diminished by 4 times in Falesti district and by 3 times in Glodeni district. This trend is determined both by worsening economic situation in agriculture and intensifying aridity processes as well as by the spread of 
the phenomenon of incomplete registration of water volumes used for these purposes, especially, for irrigation.

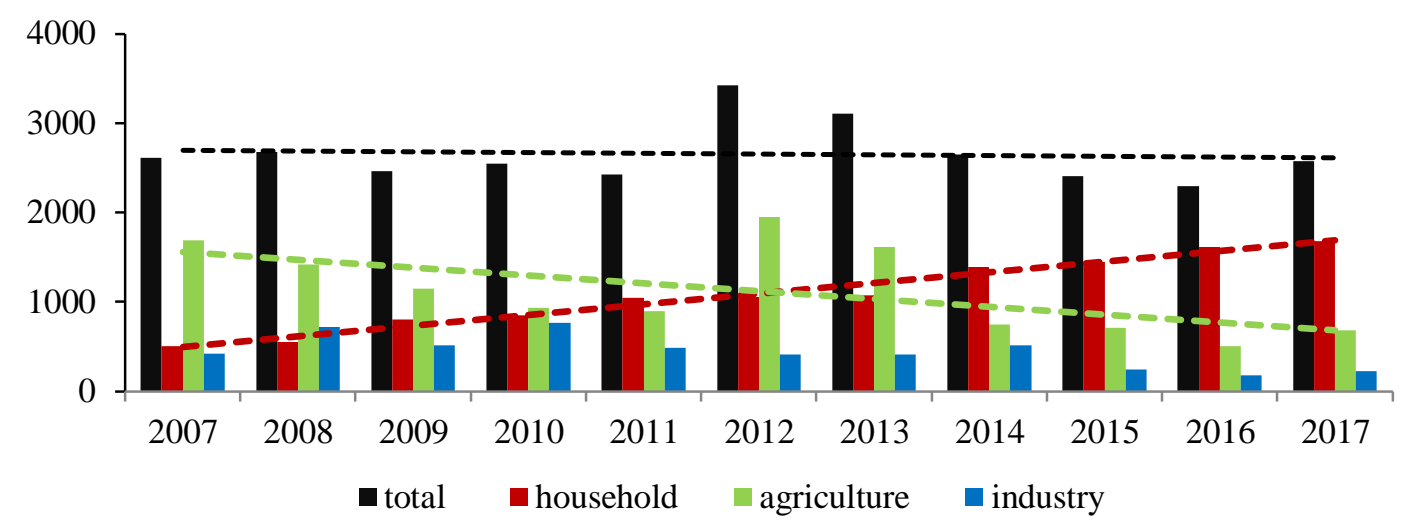

Figure 4. Dynamics of the volume of water used (in ths. $\mathrm{m}^{3}$ ) in the Camenca river basin, by wateruse categories. Data sources: AAM 2007-2017, NBS 2007-2017, IPM 2018.

The volume of water used for household needs has constant and very positive dynamics (Figure 4), which is due to the significant expansion of the communal water supply systems and the similar increase of metered water consumption for these purposes. Thus, in the Camenca RB, the volume of water used for these needs increased by 3.3 times (from about 500 ths. $\mathrm{m}^{3}$ to $\approx 1.7$ mil. $\mathrm{m}^{3}$ ), including in Rascani district - by 4.7 times, in Falesti district - by 4 times and in Glodeni district -by 2.4 times.

The total volume of water used for technological purposes shows an oscillating evolution against the background of a general negative trend, marked by the regress in agro-industrial complex and, especially, by the reduction of sugar production at factories from Glodeni and Falesti.

In 2017, as a result of the significant extension of the communal aqueducts in the rural settlements, as well as due to the reduction, by over 2 times, of the volume of water used for agricultural and technological purposes, the share of these wateruse categories differs very much from the average share of analyzed period. Thus, for agricultural purposes there were used only 677 ths. $\mathrm{m}^{3}$ or $1 / 4(26 \%)$ of the total volume of water used. For household needs there were used $1.7 \mathrm{mil}^{3} \mathrm{~m}^{3}$ or $65 \%$ of the total volume, and in the districts Falesti and Glodeni - over 70\%. At the same time, a large part of the household water delivered to the population is widely used for growing plants and domestic animals, etc. For technological needs there were used 254 ths. $\mathrm{m}^{3}$ $(9 \%)$ or $\approx 2$ times less than the average of the analyzed period, which is due, almost exclusively, to the similar reduction of the volume of water used by sugar factories, especially from Glodeni town. 


\subsubsection{Reduced assurance with centralized public water supply and sanitation systems}

Centralized water supply systems are present in 43 (57\%) of the 75 settlements located in the Camenca river basin. The highest level of aqueduct assurance is attested in Rascani district, to which all 15 settlements within the basin are connected. In Glodeni district there are 16 settlements or $\approx 1 / 2(48 \%)$, including 13 of 15 resident villages, connected to aqueduct. In Falesti district only 12 settlements (44\%), including 8 resident villages, have access to aqueducts. In Glodeni and Falesti districts, the absolute majority of small villages does not have centralized water supply systems. The total length of communal aqueducts in the Camenca river basin is $\approx 500 \mathrm{~km}$, including $186 \mathrm{~km}(38 \%)$ in Glodeni district, $161 \mathrm{~km}(32 \%)$ in Falesti district and $149 \mathrm{~km}(30 \%)$ in Rascani district (Table 3). The most extensive aqueducts are in Falesti $(45 \mathrm{~km})$ and Glodeni $(35 \mathrm{~km})$ towns, as well as in villages of Rascani district.

Table 3. The state of public water supply systems in Camenca river basin

\begin{tabular}{|c|c|c|c|c|c|c|c|c|}
\hline \multirow[t]{2}{*}{ Districts } & \multirow{2}{*}{$\begin{array}{l}\text { Length of } \\
\text { aqueducts }\end{array}$} & \multirow{2}{*}{$\begin{array}{c}\text { Number of } \\
\text { connected } \\
\text { people }\end{array}$} & \multirow{2}{*}{$\begin{array}{c}\text { Access of } \\
\text { the people, } \\
\%\end{array}$} & \multirow{2}{*}{$\begin{array}{c}\text { No of } \\
\text { connected } \\
\text { households }\end{array}$} & \multicolumn{2}{|c|}{ Pumping stations } & \multicolumn{2}{|c|}{ Artesian wells } \\
\hline & & & & & total & working & total & working \\
\hline & 149 & 8334 & $64 / 67$ & 3102 & 0 & 1 & 22 & 18 \\
\hline & 18 & 21086 & 46 & 7659 & 20 & 16 & 23 & 23 \\
\hline Falesti & 161 & 22927 & $57 / 77$ & 8459 & 20 & 20 & 33 & 20 \\
\hline Camenca RB & 496 & 52347 & $53 / 68$ & 19436 & 40 & 38 & 77 & 58 \\
\hline
\end{tabular}

Data sources: NBS 2007-2017

As a result of the recent aqueducts extension, an average level of the population's access (53\%) to this service was reached (Table 3). The highest access of population to the aqueducts is observed in Rascani district, in which about $2 / 3$ of the population of the settlements located in the Camenca river basin is connected. In Falesti district, $\approx 60 \%$ of the population has access to centralized aqueducts, and in Glodeni district - less than half. The maximum level (>80\%) of population access is attested in the Falesti and Glodeni towns, as well as in the villages Parjota, Alexandresti and Galaseni from the Rascani district, Pruteni from Falesti district.

At the same time, for the absolute majority of the artesian wells the authorization for water use is missing or has expired. Except Falesti towns, the water pumping stations capacity does not exceed 10 ths. $\mathrm{m}^{3}$ /day. It should be note that, only about $1 / 3$ of the project capacities of the stations built in the Soviet period is used, including those from Glodeni and Falesti towns. The most of the artesian wells and aqueducts are worn out.

About $90 \%$ of the water delivered by the municipal enterprises is destined to the households, and the rest of $10 \%$ to the budgetary organizations (5\%) and to the 
economic agents (5\%). Among budget organizations, those that are remarked are the medical and training centers and the buildings of local public administration. Water volume delivered to economic agents depends on the number and production capacity of the enterprises which do not have their own water sources, particularly agricultural and complex markets, technical service stations, car wash stations, gas stations, etc. The municipal enterprises from Glodeni and Falesti towns delivered over $1 / 2$ (55\%) of the total volume of water used (NBS, 2007-2017).

Despite the rapid expansion of water supply system, the water consumption per person is by 2 times lower (47 1/day per person) than the country average, which is due to the lower degree of urbanization in this river basin. Also, the water consumption per person is directly conditioned both by the length of the aqueducts and by the number of the connected population, as well as by the quantity and quality of the local water resources.

The public sewerage systems are operated only in Glodeni and Falesti towns, as well as in only 5 from 73 rural settlements. In addition, in most of these villages only public institutions (school, kindergarten and town hall) are connected to the public sewerage networks. The total length of the sewerage network in the Camenca RB is $\approx 70 \mathrm{~km}$, including $32 \mathrm{~km}(46 \%)$ in Falesti town, $18.2 \mathrm{~km}(26 \%)$ in Glodeni town, $12 \mathrm{~km}$ in the residential district of the Falesti sugar factory. Unfortunately, we identified that the rapid expansion of aqueducts is not accompanied by the similar extension of sewerage networks and sewerage systems, which significantly increases the impact on aquatic ecosystems and on the population. The absolute majority of wastewater received by public sewerage networks is insufficiently treated (Falesti) or untreated (Glodeni). A similar situation can be seen in the case of water discharged directly from industrial and transport companies.

Wastewater treatment plants are present only in Falesti and Glodeni towns, as well as in Limbenii Vechi village, at the school from Cuhnesti and at the Multifunctional Community Center from Balatina, but they are in an advanced state of wear. In addition, due to the cessation of the activity of the Glodeni sugar factory, its wastewater treatment plant, which previously received water from the urban sewage network, is no longer working. As a result, the entire volume of discharged wastewater from Glodeni town is transported, without treatment, to the storage tanks of the respective factory, which are already overloaded and present a serious danger to the aquatic ecosystems and human health in the respective area.

\subsubsection{Status and use of non-centralized sources of water supply}

Population water supply in the settlements of the Camenca RB is largely ensured by

the non-centralized water sources. According to data from State Ecological Inspectorate, 9623 wells were identified in the Camenca RB, of which 4927 in Glodeni L.S.G.D.C. 47 (1): $75-97$ 
district, 2642 in Falesti district and 2054 in Rascani district. Overall, 87\% of the wells are arranged and can be used as a source of water for population, plants cultivations and animals feeding. At the commune level, the number of wells depends both on the commune size and on available groundwater reserves. Also, for water supply there are used 238 springs, of which $\approx 60 \%$ are arranged (IPM 2018). At the level of settlements and districts, the number of springs depends on their hydrological characteristics. In addition, official data on this subject are influenced by activity of recording and monitoring water resources, including springs and wells, performed by the ecological and sanitary authorities. This explains the net lower number of springs and the much better state of reservoirs and springs in Falesti district.

Table 4. The number and status of wells and springs from the Camenca river basin (2017)

\begin{tabular}{|c|c|c|c|c|c|c|}
\hline \multirow[t]{2}{*}{ Districts } & \multicolumn{3}{|c|}{ Wells } & \multicolumn{3}{|c|}{ Springs } \\
\hline & total & arranged & $\%$ & total & arranged & $\%$ \\
\hline Rascani & 2054 & 2006 & 98 & 62 & 24 & 39 \\
\hline Glodeni & 4927 & 3941 & 80 & 155 & 103 & 66 \\
\hline Falesti & 2642 & 2387 & 90 & 21 & 14 & 67 \\
\hline Camenca RB & 9623 & 8334 & 87 & 238 & 141 & 59 \\
\hline
\end{tabular}

Data source: IPM 2018

Another important source of water supply, insufficiently reflected in official statistics, is represented by the reservoirs and ponds. Their total number is of 484 reservoirs, with a total area of about 3.5 ths. ha. The majority of the reservoirs (169 of 178) are of general use are on public property, being managed by the mayoralties. Those of fishery destination are managed by private operators, including people from outside of the Camenca river basin. Most of these reservoirs were built during the last century, in the 70-80s, for flow regulation and fisheries. The largest ones were managed by large fish farms, which were later transferred to self-management or privatized. The number of reservoirs and their surface are conditioned by districts' areas and by the length of the streams, on which these are frequently built, as well as by the presence of the above-mentioned fish farms.

Only 14 reservoirs are used for irrigation, of which 9 are located in Rascani district, in the upper course of the Camenca river, being destined for the supply of the large farms. In Glodeni and Falesti districts only 4 reservoirs are mainly destined to fishery. A large part of the reservoirs and ponds of general use are used, mainly for irrigation purposes. Unfortunately, most of these reservoirs do not have a permit to be used and do not comply with the regulations for the use and protection of water bodies. At the same time, the condition of the hydro-technical structures is unsatisfactory. 


\subsubsection{Human impact on water bodies}

The assessment of human pressures and impacts on water bodies was performed in order to assess the status of water bodies and to identify those that are at risk of not achieving the WFD objectives. This assessment included the following basic steps: identification of water use and associated pressures and the assessment of the risk of a possible failure to achieve the environmental objectives. The main pressure types within the Camenca river basin are the following: wastewater discharge, agricultural activities, unauthorized dumps, interruption of longitudinal continuity of rivers (Jeleapov and Jeleapov, 2018).

Point pollution sources. Assessment of point pollution source impact on the status of river water bodies was calculated as a ratio of the data on total wastewater discharges and the river water body mean flow. Application of this method resulted in the fact that a significant impact is identified for the Sovatul de Jos WB, and average for the Sovatul Mic and Sovatul Mare (the lower part) (figure 6), being low for the others. However, when evaluating the collected database on abstracted and discharged water, it was identified that the volume of the last one is minor or practically null compared to the first one. From another point of view, as shown above and below, the confidence level in data base on water use cannot be considered very high, thus, the results of this method cannot represent the real situation on point pollution sources impact on water resources. For increasing the confidence level, better monitoring and management of water abstraction, use and discharge is recommended.

Diffuse pollution sources. The assessment of diffuse pollution sources impact on the status of river water bodies has been made by estimation of agricultural activities and livestock impact as suggested in the European methodology on this subject (Vogel, 2014). Agricultural activities impact is determined by the share of arable land relative to the basin area (if it is $<10 \%$ - no impact - WB not at risk, if it is $>30 \%$ - high impact - WB at risk). Considering the fact that the arable land occupies fairly large areas within the water bodies basins (Figure 3), this factor influences significantly the rivers quality state. The average impact is estimated for one water body, the Camenca (the lower course), mainly due to the fact that "Padurea Domneasca" (Royal Forest) scientific reserve is located here. The impact of livestock is lower for 3 water bodies: the Camenca WB (middle and lower course), the Glodeanca WB (upper course) and average for 9 water bodies. It should be noted that birds were not taken into account in the calculations, thus this indicator may be higher. Finally, by aggregating the pressure from identified diffuse sources, 11 of 12 water bodies are under high 
pressure and only 1, respectively, the Camenca WB (lower course), is under average pressure (Figure 7).

Hydrologic and hydro-morphological alterations. The assessment of the human impact on hydro-morphological status of water bodies was performed on the basis of analysis of reservoirs build in cascade on water bodies streams, flood protection embankments and irrigation/drainage channels located near riverbeds. Construction of reservoirs in cascade resulted in water bodies length reduction. Within the pilot basin, all water bodies are subject to this type of pressure. Protection embankments are built in the Camenca river (lower course) basin and do not significantly affect the water body status. On the other hand, the large number of drainage/irrigation channels within the same water body determines us to classify their impact as high. Channels built near other water bodies do not significantly affect their status. As a result, it should be mentioned that the hydromorphological status of water bodies is significantly influenced by anthropogenic activity, generally by construction of reservoirs (Figure 8), but also by channels, especially in the lower part of the Camenca river.

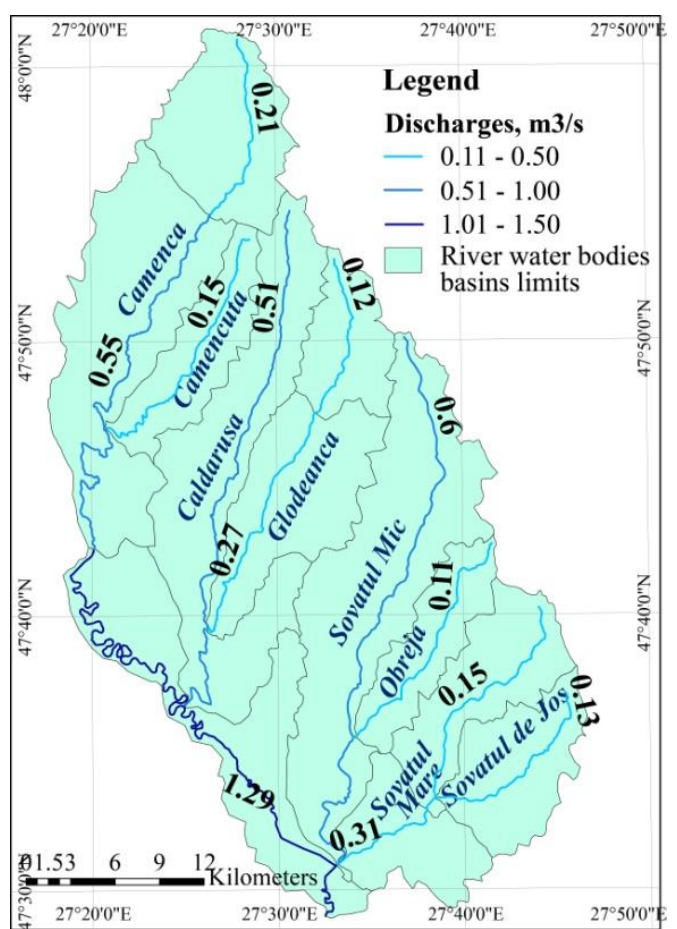

Figure 5. Estimated discharges of the river water bodies

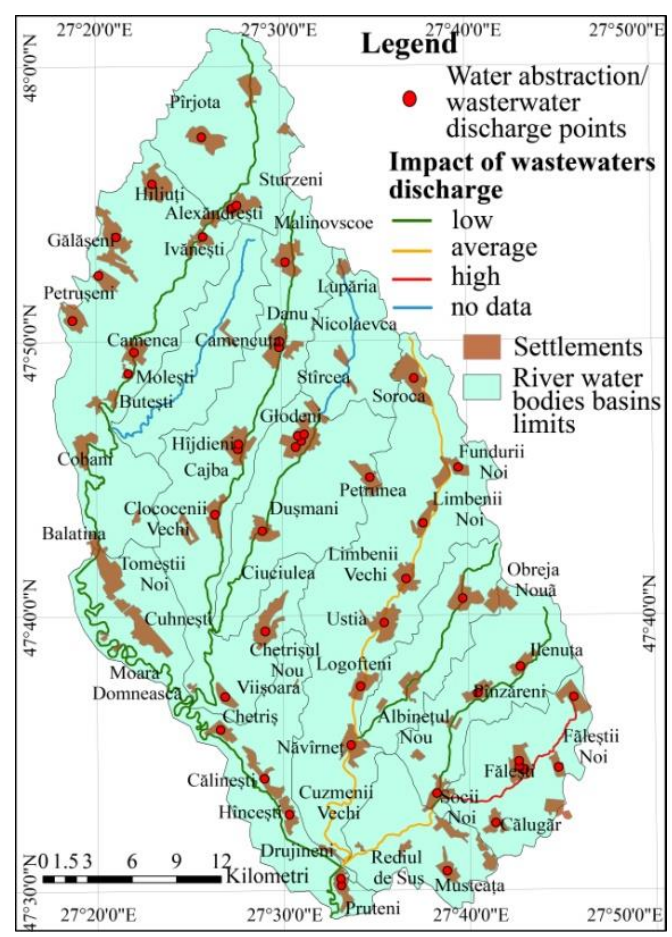

Figure 6. Impact of wastewater discharge 


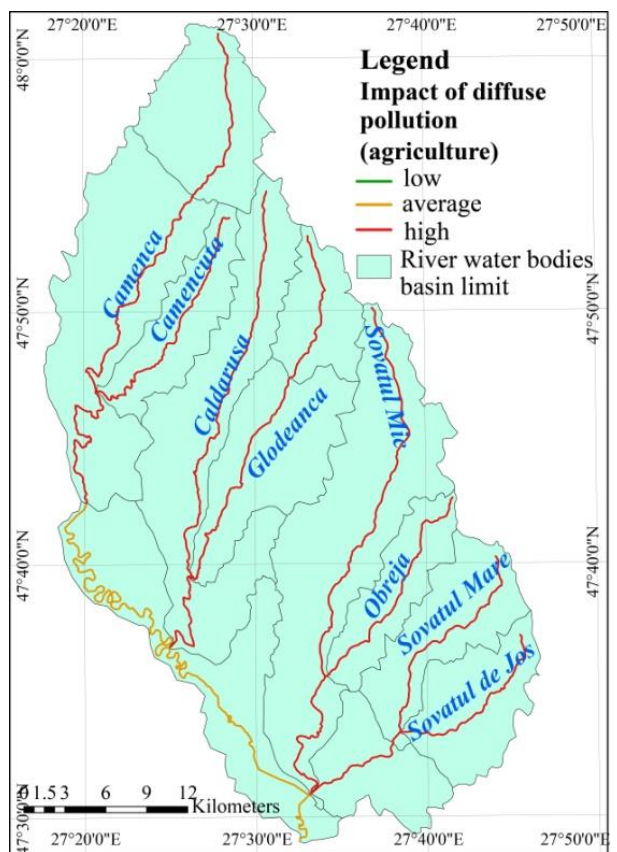

Figure 7. Diffuse pollution impact

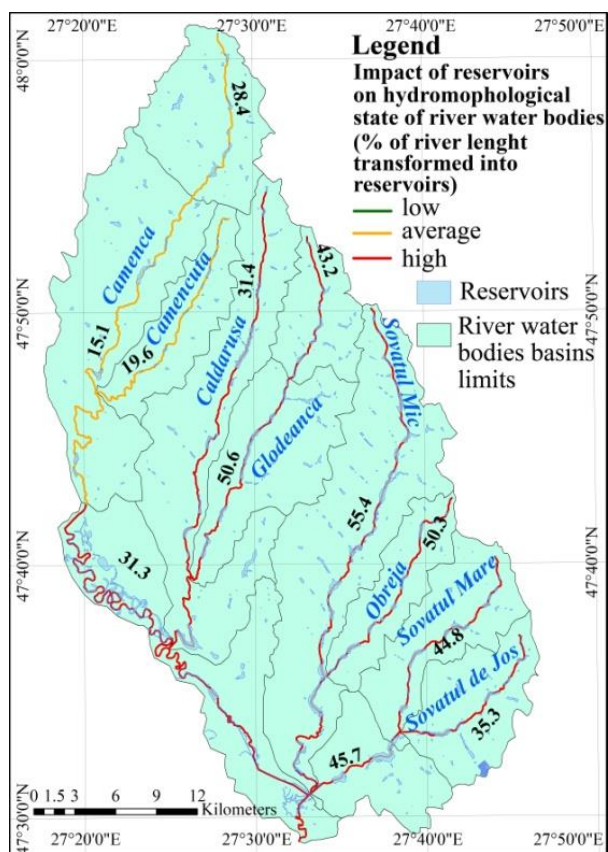

Figure 8. Impact of reservoirs on hydro- morphological state of water bodies

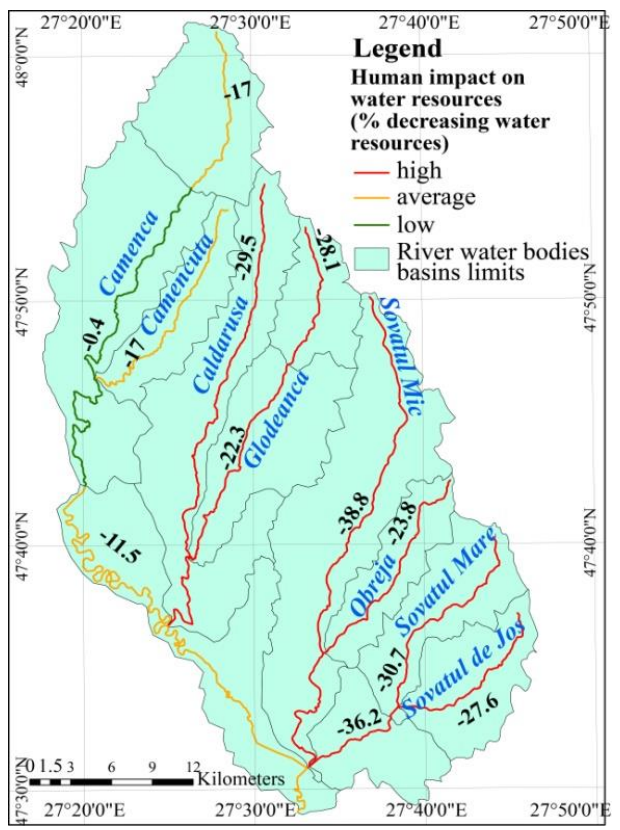

Figure 9. Cumulative human impact on water resources of water bodies

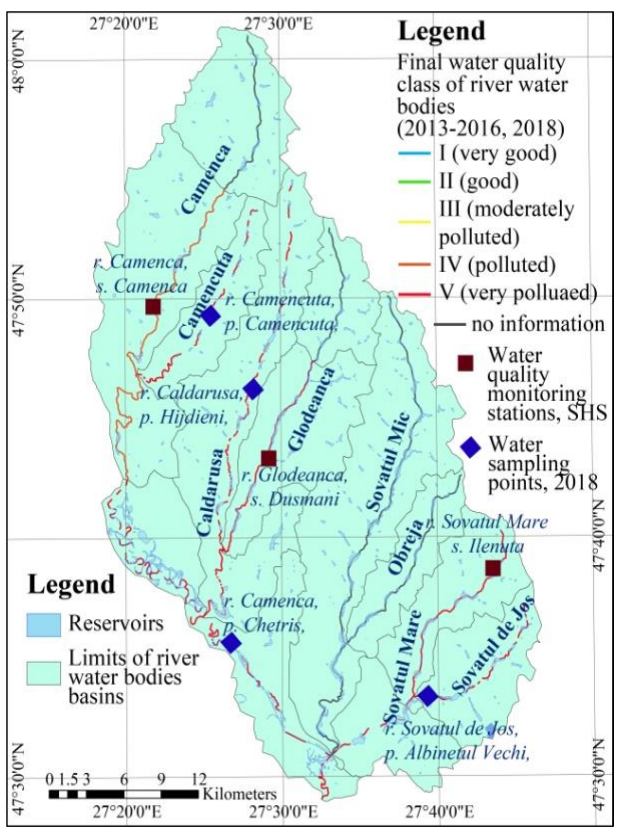

Figure 10. Water quality class (constructed based on measurements in the field and Anuarele privind starea calitatii apelor de suprafata) 
Assessment of anthropogenic activity impact on water bodies water resources was carried out based on analysis of agricultural practices, urbanization processes and reservoirs. Reservoirs determine reduction of water resources due to increased evaporation processes (as described and suggested in (CP D.01.05-2012, 2013). These cause the decrease of water resources by about $12-44 \%$ (Figure 8 ). The impact of agriculture practices reduces the water resource by 5-6\%, while urbanization processes increase them by, on average, 12\%. Minimal increase due to the last factor is specific for the Camencuta WB - 1.1\%, and maximal - for the Sovatul de Jos WB $22.4 \%$ - where Falesti town is located. For 9 WB the impact of urbanization leads to an increase in surface runoff by over $10 \%$. At the end of assessment of the cumulative human impact on water resources, we conclude that only for one water body within the Camenca river basin the water resources remain practically unchanged, for 3 bodies they decrease up to $20 \%$ and for the other 8 , the decrease of river runoff is considerable, being approx. 40\% (Figure 9). As a result of assessment of human impact on the water bodies of the Camenca RB, and estimation of water quality parameters as shown in Figure 10 it was found that the water is very much polluted. All 12 river water bodies were identified as being at risk of failing the WFD environmental objectives.

\subsection{Problems of water resource management}

\subsubsection{Shortcomings of information system and institutional framework}

The challenges in utilization of water resources in the Camenca river basin are not only caused by the acute deficit of drinking water resources, but also by the inefficient water management.

As a result of collection and processing of data obtained from Apele Moldovei (Moldova Waters) Agency, the Inspectorate for Environmental Protection (IPM) and the National Bureau of Statistics (NBS), we noticed the lack of a centralized information system in the field of water resources and water use, as well as the presence of different data for the same indicators of water management provided by mentioned responsible authorities. Also, the official statistical data include only the measured metered water consumption. For this reason, based on the data from the Inspectorate of Environmental Protection, the non-centralized sources of water supply were analyzed, which, as a rule, do not keep track of the water used, including the reservoirs, wells and springs.

The information on the indices of water management on sub-basins is missing, fact which creates major difficulties in selecting and processing existing data. Other important problems are: the lack of records of water use for fishery and recreational purposes, high share of unmetered water consumption and water loss (70\%). 
In the process of water resources management, various involved departmental structures represent, as a rule, formal competences, and their functions frequently overlap. This is the case, especially, for the functions like water use registration, water resources evaluation and control, monitoring network, which include only the main water courses and an insignificant number of reservoirs. In addition, the competences of the "Apele Moldovei" Agency are limited, especially, regarding the surface water sources, destined for irrigation and other agricultural and fishery needs. Also, unlike Romania, most of the water management functions are not exercised on hydrographic basins, but on administrative-territorial units (districts).

\subsubsection{The problems of costs recovering from water use}

The recovery of operational costs of utilized water resources is obtained mainly from the tariffs for provision of respective services, permits for sport fishery, access to recreational areas. The taxes are applied for water use, for pollutants discharges and wastewaters, as access permits, as well as transfers from the public budget and donors in order to recover the costs for application of measures for the management, protection and restoration of water bodies and their protection zones, for the maintenance of public utility of water bodies (recreational swimming, amateur fishery).

The amount and procedure for application of tariffs for public water supply, sewerage and treatment services are stipulated in the Decision no. 741 of the National Agency for Energy Regulation (NAER) of 18.12.2014 (ANRE 2014). The current methodology is in accordance with the provisions of the Law nr. 303 of 13.12.2013 on public water supply and sewerage services (RM Law, 2013) and of the Water Law (RM Law, 2011). Also, this methodology is adjusted to Article 9 of the WFD and is based on the principles "beneficiary and polluter pays" and "the costs recovering of water use" from the tariff of water supply and sanitation services. Meanwhile, tariff shares for water supply and sewerage services are set only on categories of users and their ability to pay, but not on the total value of the water sources. Tariffs for public water supply, sewerage and wastewater treatment services are applied for 3 main categories of consumers for which separate tariff rates are set: 1) the population; 2) budget organizations; 3 ) economic agents.

The most important categories of costs, which determine the approved tariffs, are the costs of labor remuneration and the expenses for the electricity required for pumping water to the supply network and the wastewater to the sewerage network. These costs are conditioned by the daily water supply capacities (flow) of the abstraction source, its geographic location, and the peculiarities of the settlement or perimeter between the source and final consumers. At the same time, the tariff quote for households does not depend on the amount of water used and on the reserves 
available for uninterrupted supply of drinking water, which de facto represents a major lack of this Methodology and, particularly, an alarming problem for the population and local public authorities (LPA). Excessive consumption in some households, including for irrigation, industrial animal breeding, auto services, etc. significantly affect the available water resources and the capacities of local operators to provide drinking water to the population throughout the year (Bejan et al., 2019). Therefore, it is necessary to modify the actual Methodology in regard with application of differentiated rates of water supply tariffs depending on the volume of water consumed per households, as well as on the degree of assurance with qualitative water at local and regional level.

The quota of tariffs for water supply in the settlements of the Camenca river basin is, on average, $14.7 \mathrm{MDL} / \mathrm{m}^{3}$. The maximum quota of $16.4 \mathrm{MDL} / \mathrm{m}^{3}$ of delivered water is set in the settlements from Glodeni district, and the minimum quota of 12.3 $\mathrm{MDL} / \mathrm{m}^{3}$ - in the settlement from Rascani district with public aqueducts. In most rural settlements, which have centralized aqueducts, the average tariffs are 10-15 $\mathrm{MDL} / \mathrm{m}^{3}$ (AMAC, 2018).

In 2010-2018, a considerable increase (about 50\%) of the tariffs for water supply was detected in the absolute majority of settlements from the Camenca river basin. Slower growth is observed in Falesti city $(+42 \%)$ and in rural settlements with a more difficult socio-economic situation (villages in the Prut floodplain) or, where local councils have strongly opposed the tariff increase. Despite the increase in tariffs, the cost of water supply services exceeds the tariffs for these services with about 1 $\mathrm{MDL} / 1 \mathrm{~m}^{3}$, and the negative differences are recorded in the most settlements from the Camenca RB. Current tariffs allow costs recovery from municipal companies of settlements that have new aqueducts and do not require additional maintenance costs, even if tariff quota is relatively low $\left(10-15 \mathrm{MDL} / \mathrm{m}^{3}\right)$. At the same time, in the settlements with a high degree of aqueduct wear, the operational costs significantly exceed the tariffs. To repair the hydro-technical installations, constantly the reference is to the local budgets, which have very modest capacities.

The Methodology for calculation of tariffs for wastewater sewerage and treatment services does not include the regulatory costs needed to protect and restore the natural basins where wastewater is discharged as well as possible damage to aquatic ecosystems and water bodies. Also, the current tariffs applied for provision of sewerage and wastewater treatment services in Falesti and Glodeni towns do not allow to recover the costs of those services, or even more, to implement measures to improve water resources and water bodies (Bejan et al., 2019). In Falesti town, the costs of the respective services $\left(16.2 \mathrm{MDL} / \mathrm{m}^{3}\right)$ exceed the established tariff, on average, by $1.4 \mathrm{MDL} / \mathrm{m}^{3}$. In the Glodeni town, despite much higher tariffs, especially for wastewater discharge, received from budgetary organizations and economic 
agents, the average cost $\left(25.8 \mathrm{MDL} / \mathrm{m}^{3}\right)$ exceeds by $2.0 \mathrm{MDL} / \mathrm{m}^{3}$ the average tariff for the respective services. This finding speaks to us about the very low profitability of the respective operator and serious problems of the communal sector from Glodeni town, which must be a priority action during implementation of the Programme of Measures of the Camenca river basin management plan.

Therefore, in this management cycle (cycle II, 2019-2024), the recovery of full costs of water use, at the level of the Camenca river basin, will not be possible. In the initial period, more studies are needed on the evaluation of the efficiency of the use of water at the level of settlement or urban agglomerations, at the request and with the active implication of local and district councils, especially, on the platform of subbasins committees. In addition, it is imperative to carry out the audit of municipal water supply and sanitation enterprises, especially those with low profitability, in order to identify the main problems, but also to develop viable recommendations for optimization of the respective companies. Despite the high costs of audit procedures, public authorities must contribute in compensation of these measures, without which the respective sector cannot be effective.

Tax for water use. Despite its simplicity, the current methodology for calculating payments for water consumption contains a number of gaps: a) the quantum equal to $1 \mathrm{~m}^{3}$ of water abstracted from surface and groundwater sources; b) the water supply is poorly reflected; c) tax rates are not conditioned by complex value and price of water, but by reduced payment capacity; d) the ecological status of surface water and groundwater is not taken into account; e) recirculation and water savings are not stimulated; f) tax rates are not established on the river basin, but on the administrative-territorial units. Due to the small quotas, unadjusted to the inflation rate, the sum of the collected funds does not allow the adequate supplementation of the costs necessary to restore the state of water resources and aquatic ecosystems. Therefore, the current mechanism of water consumption taxes is focused only on getting fiscal effects, while the economic and environmental effects are insignificant.

Charges for water pollution. Similar to the water use tax, the means of collecting water pollution payments should be used to implement public measures to maintain and improve water resources and their protection areas. Environmental authorities do not have the qualified staff and technical equipment necessary for the effective monitoring of pollution sources. As a result, the polluters with small and medium impact, and public institutions, are not monitored and do not pay for pollution. At the same time, due to very low normative payment for wastewater discharges, industrial polluters often prefer not to use their own wastewater treatment systems and benefit from the services of municipal wastewater treatment plants, which were not initially designed for treatment of industrial wastewaters. 
Due to acute shortage of technical equipment and accredited staff, most of the damage caused to waters is not assessed and is not subjected to compensation. Usually, there are applied actions for damage compensation in cases of the unauthorized abstracted/used of water and only in rare cases for unauthorized discharges of polluted wastewater.

\subsubsection{The problems of subsidizing the measures of rational use and protection of water resources}

Despite the multiple increases in the number and amounts of NEF (National Ecologic Fund $)^{2}$, almost all allocations are still intended to extend the public water supply systems. There are no financing projects for the cleaning of communal ponds, most of which have a critical ecological and sanitary-hygienic status, and present a real danger to the health of the local population. A massive number of projects were approved around the parliamentary and local elections, especially before November 2014, and the sum of approved projects was not based on feasibility studies. According to the Audit Report of the Court of Accounts, this situation frequently contributes to delay in the implementation of the respective projects and the partial and non-qualitative execution of some important works, especially those related to the sewerage and wastewater treatment system in rural areas. Also, the NEF has frequently accepted to finance the subsequent installments, as previous steps have not been fully realized or the beneficiaries have not presented the set of confirmatory documents. In addition, investment projects were approved in the absence of the necessary financial resources. The absolute majority of NEF-funded projects, including complex ones, do not exceed the limits of a commune. The approval of the projects did not take into account the current trends of depopulation of the rural area, which included over $80 \%$ of the settlements in the north of the Republic, as well as the real economic opportunities for development of the selected settlements.

\section{Conclusions}

The Camenca river basin is poorly assured with surface and underground water resources. Due to their low flow, the streams from the Camenca river basin have only a local economic importance. As a result of intensification of climate change and the significant reduction of the surface runoff due to the excessive number of reservoirs, acute water deficit is observed in several rural settlements.

In the analyzed period, the total volume of water used in the Camenca river basin shows an oscillating evolution. The volume of water used for agricultural purposes

\footnotetext{
${ }^{2}$ funded projects for the protection of water resources and the implementation of complex and major projects in this area
} 
was reduced by 2.5 times and the volume of water used for technological needs by $\approx 2$ times. In the same time, the volume of water used for household needs shows a pronounced increase (by 3.3 times), which is due to the significant extension of the public aqueducts and of metered water consumption. This fact is not accompanied by the similar extension of sewerage networks and treatment plants, which significantly increases the human impact on water bodies. Despite the rapid extension of aqueducts, only a half of the inhabitants from the Camenca river basin has access to qualitative water delivered by public aqueducts and the water consumption per person is very low (47 $1 /$ day). In addition, the public sewerage system is operated only in Glodeni and Falesti towns, as well as in only 5 out of 73 rural settlements from the study area.

The hydro-morphological status, hydrological regime and water quality of the 12 water bodies are strongly influenced by human impact. Due to diffuse and point sources pollution all river water bodies are highly polluted. A significant impact is determined by reservoirs that cause decrease of the water bodies lengths by $20-55 \%$, and of water resource by $12-44 \%$. The tributaries of the Camenca river: Caldarusa, Glodeanca, Sovatul Mic, Sovatul Mare and Sovatul de Jos as well as the lower course of Camenca river are highly modified.

\section{References}

ANAR - Administratia Nationala „Apele Romane” (2016). Planul de management al spatiului hidrografic Prut Barlad. Ciclul II. Available online: http://www.rowater.ro/daprut/ default.aspx (accessed on 16.02.2019).

AAM - Agenţia „Apele Moldovei” (2007-2017). Rapoartele anuale generalizate privind Indicii de gospodarire a apelor în Republica Moldova.

AMAC - Asociatia „Moldova Apa-Canal” (2018). Indicii financiari si de producție ai activitații intreprinderilor de alimentare $\mathrm{cu}$ apa si canalizare. Chisinau, Available online: http://www.amac.md/doc.php?l=ro\&idc=15\&id=179 (accessed on 17.01.2019).

Bejan, I., Boboc, N., Bacal, P., Nedealcov M., Jeleapov A., Angheluță V., Zgîrcu N. (2016). Planul de gestionare al bazinului hidrografic Prut. Ciclul I, 2017-2022. Chisinau, 116 p.

Bejan, I., Bacal, P. Nedealcov M., Jeleapov A., Jeleapov V., Zgîrcu N. (2019). Planul de Gestionare a Bazinului Hidrografic Camenca. Chisinau, 98 p.

Cadastru de Stat al Apelor (CDA) (2006) Date multianuale despre resursele si regimul apelor de suprafaţa. Chisinau.

Cazac, V., Mihailescu, C., Bejenaru, G. (2010). Resursele acvatice ale Republicii Moldova. Apele de suprafata. Chisinau, Ed. Stiinta. 248 p.

---Danube River Basin Management Plan - 2015-2021 (2014). Available online: www.icpdr.org (accessed on 17.07.2019)

---Determinarea caracteristicelor hidrologice pentru conditiile Republicii Moldova. Normativ în constructii CP D.01.05-2012 (2013)., Ediție oficială. Chișinău, 2013. 155 p. 
Directive 2000/60/EC establishing a framework for Community action in the field of water policy.

Directive 2006/118/EC on the protection of groundwater against pollution and deterioration.

Directive 91/676/EC on the protection of waters against pollution by nitrates from agricultural sources

NGF - Fondul national de date geospatiale al Republicii Moldova (2018). Official website. (online) Available at www.geoportal.md (accessed on 17.04.2019)

Guidance document no. 1. (2003). Economics and the Environment. The Implementation Challenge of the Water Framework Directive. Luxembourg: Office for Official Publications of the European Communities.

Hotararea ANRE nr. 741 din 18.12.2014 privind „Metodologia de determinare, aprobare si aplicare a tarifelor pentru serviciul public de alimentare cu apa, de canalizare si epurare a apelor uzate" În: Monitorul Oficial nr.33-38 din 13.02.2015. În: Monitorul Oficial nr. 258-261 din 15.11.2013.11]

IPM - Inspectoratul pentru Protectia Mediului (2018). Anuarele privind calitatea factorilor de mediu si activitatea Inspecțiilor Ecologice

Jeleapov, A., Jeleapov, V. (2018). Starea hidromorfologica a corpurilor de apa din bazinul hidrografic al raului Camenca. In: Biodiversitatea în contextul schimbarilor climatice: Chisinau, "Biotehdesign", p. 250-256.

Law of the Republic of Moldova (RM Law) (2011). Legea apelor nr. 272 din 23.12.2011. Inn: Monitorul Oficial nr. 81 din 26.04.2012

Law of the Republic of Moldova (RM Law) (2013). Legea nr. 303 din 13.12.2013 privind serviciul public de alimentare $\mathrm{cu}$ apa si canalizare (în vigoare din 14.09.2014). În: Monitorul Oficial nr. 60-65 din 14.03.2014.

NBS - National Bureau of Statistics (2007-2017). Rapoartele anuale privind activitatea sistemelor de aprovizionare cu apa si canalizare 2007-2017.

NBS - National Bureau of Statistics (2005, 2015). Recensamîntele populatiei 2004, 2014. Available online at: http://www.statistica.md/map.php?l=ro\&idc=205 (accessed on 15.07.2019).

RMGD (2018). Republic of Moldova Government Decision no 955 / 30.10.2018 - cu privire la aprobarea Planul de gestionare a districtului bazinului hidrografic Dunarea-Prut și Marea Neagră. In : Monitorul Oficial, no. 448-460 (07.12.2018).

RMGD (2017). Republic of Moldova Government Decision no 814 / 17.10.2017 - cu privire la aprobarea Planul de gestionare a districtului bazinului hidrografic Nistru. In: Monitorul Oficial, no. 371-382 (27.10.2017).

RMGD (2013a). Republic of Moldova Government Decision no. 881 / 07.11.2013 - pentru aprobarea Metodologiei privind identificarea, delimitarea si clasificarea corpurilor de apă. In: Monitorul Oficial, no 258-261 (15.11.2013).

RMGD (2013b). Republic of Moldova Government Decision no 890 / 12.11.2013 - privind aprobarea Regulamentului cu privire la cerintele de calitate a mediului pentru apele de suprafata. In: Monitorul Oficial, no 262-267 (22.11.2013).

SHS - Serviciul Hidrometeorologic de Stat (2011-2017). Anuarele privind starea calitatii apelor de suprafata conform elementelor hidrobiologice si hidrochimice pe teritoriul Republicii Moldova, 2010-2017. 
US Geological Survey, Earth Explorer (2018). Official website, Shuttle Radar Topography Mission (SRTM), https://earthexplorer.usgs.gov (accessed on 17.04.2019).

Vogel, B. (2014). Guidance Document address-ing hydromorphology and physico-chemistry for a Pressure-Impact Analysis/Risk Assessment according to the EU WFD. Activity 2 Pilot Testing in EPIRB Project River Basins. Viena. 